\title{
Deep root uptake of leachable nitrogen in two soil types is reduced by high availability of soil nitrogen in fodder radish grown as catch crop
}

\author{
Yue Xie • Sarmin Islam • Haftom Teka Legesse • \\ Hanne Lakkenborg Kristensen (1)
}

Received: 11 August 2020 / Accepted: 23 April 2021 / Published online: 21 May 2021

(C) The Author(s) 2021

\begin{abstract}
Aims Plant available soil nitrogen (N) may affect deep root growth and soil $\mathrm{N}$ depletion by catch crops. We investigated the influence of topsoil $\mathrm{N}$ availability on root growth and uptake by fodder radish.

Methods We conducted field and greenhouse experiments of root growth and late autumn $\mathrm{N}$ uptake at medium and high soil $\mathrm{N}$ availabilities, and $\operatorname{root} \mathrm{N}$ inflow at medium and deep soil depths $\left({ }^{15} \mathrm{~N}\right.$ injection) in sandy loam and loamy sand, using the minirhizotron method in the field and rhizotrons in the greenhouse.

Results High soil N availability resulted in lower root intensity in the field, but higher root intensity in the greenhouse experiment under both soil types. Radish had deeper roots and higher root intensity in sandy loam than in loamy sand. High soil $\mathrm{N}$ availability caused lower ${ }^{15} \mathrm{~N}$ uptake at both soil depths in the field and lower $\mathrm{N}$ inflow rates at both soil depths in field and greenhouse. At medium soil $\mathrm{N}$ availability in the field, $\mathrm{N}$ inflow was twice as high in the deep than in the medium depth.
\end{abstract}

Responsible Editor: Hans Lambers.

Y. Xie

Department of Vegetables, College of Horticulture, China

Agricultural University, Beijing, China

Y. Xie · S. Islam • H. T. Legesse $\cdot$ H. L. Kristensen $(\bowtie)$ Department of Food Science, Aarhus University, Agro Food Park 48, 8200 Aarhus, N, Denmark

e-mail: hanne.kristensen@food.au.dk
Conclusions Higher soil $\mathrm{N}$ availability affects root growth and decrease $\mathrm{N}$ inflow, thus lowering late autumn $\mathrm{N}$ uptake and hampering deep $\mathrm{N}$ exploitation by fodder radish. At medium soil $\mathrm{N}$ availability, the potential for $\mathrm{N}$ uptake in deep soil is higher probably due to younger roots than at a medium soil depth. The shallower and less dense root growth in loamy sand is probably due to its lower clay and higher $\mathrm{P}$ contents.

Keywords Cover crop $\cdot$ Fodder radish $\cdot$ Nitrogen uptake $\cdot$ Raphanus sativus $\cdot$ Root growth $\cdot$ Soil type

\section{Introduction}

Autumn catch crops in temperate agroecosystems have been reported to efficiently deplete deep soil nitrogen $(\mathrm{N})$ after the main crop has been harvested, thereby reducing the risk of nitrate leaching to groundwater (Sapkota et al. 2012; Tei et al. 2020). The ability to reduce nitrate leaching varies between species and proportions in cover crop mixtures (Farneselli et al. 2018), and depends on genetic traits of root growth, degree of winter hardiness, and $\mathrm{N}$ sink capacity. For example, $\mathrm{N}$ accumulation has been shown to be as high as $167 \mathrm{~kg} \mathrm{~N}^{-1}$ in fodder radish (Raphanus sativus L. var. oleiformis Pers.), $127 \mathrm{~kg} \mathrm{~N} \mathrm{ha}^{-1}$ in winter rape (Brassica napus L.), $144 \mathrm{~kg} \mathrm{~N} \mathrm{ha}^{-1}$ in mustard (Sinapis alba L.) and $85 \mathrm{~kg} \mathrm{~N} \mathrm{ha}^{-1}$ in ryegrass (Lolium multiflorum Lam.) (Thorup-Kristensen 1994). Soil inorganic $\mathrm{N}\left(\mathrm{N}_{\text {inorg }}\right)$ in deep soil layers is more easily leached to groundwater because it cannot be assimilated by shallow-rooted catch crops, such as ryegrass (Kristensen 
and Thorup-Kristensen 2004a; Sapkota et al. 2012). However, catch crops from the Brassicaceae family, such as fodder radish, have been reported to extend roots to a depth of more than $2 \mathrm{~m}$ in late autumn and so are more efficient in depleting deep soil $\mathrm{N}$ than more shallow-rooted catch crops (Kristensen and Thorup-Kristensen 2004a). Rooting depth has shown a stronger correlation to $\mathrm{N}$ depletion than root density (Thorup-Kristensen 2001), whereas the root density of maize (Zea mays L.) has been reported to be related to the depletion of subsoil nitrate (Wiesler and Horst 1994).

In addition to genetically-constrained root traits, root growth is controlled by temperature (Kristensen and Thorup-Kristensen 2004a), soil moisture (Ebrahimi et al. 2014; Gabriel et al. 2012), and availability of nutrients (Kang et al. 2014), among other factors. Catch crops are generally sown after the main crop has been harvested in fields where a large amount of $\mathrm{N}$ is likely to be unused or become mineralized in the soil. Therefore, it is important to know how $\mathrm{N}$ availability in surface soil affects root development of catch crops and their abilities to uptake $\mathrm{N}$ from deep soils.

Kristensen and Thorup-Kristensen (2007) showed that rooting depth of crops is more dependent on species-specific growth attributes than on the vertical distribution of soil $\mathrm{N}_{\text {inorg. }}$. However, inconsistent effects of high soil $\mathrm{N}$ availability on root growth have also been reported for other crops depending on species and $\mathrm{N}$ status [e.g., for spring wheat (Triticum aestivum L.) (Herrera et al. 2013) and oilseed rape (Brassica napus L.) (Kamh et al. 2005)]. A modelling study by Pedersen et al. (2010) indicated that the influence of high $\mathrm{N}$ availability in soil on root density and penetration rate might delay $\mathrm{N}$ uptake from subsoils.

Apart from the indirect influence of changes in root growth on $\mathrm{N}$ depletion rates in deep soil, high $\mathrm{N}$ availability in surface soils might also have a direct influence on root $\mathrm{N}$ uptake by providing plant $\mathrm{N}$ needs in sufficient amounts, thereby reducing the need for $\mathrm{N}$ uptake from deep soil layers. For example, Gass et al. (1971) found that the ${ }^{15} \mathrm{~N}$ uptake of corn from below $1.2 \mathrm{~m}$ was less at high soil $\mathrm{N}$ concentrations than at low and medium soil $\mathrm{N}$ concentrations. In contrast, when rocket (Diplotaxis tenuifolia L.), a member of the Brassicaceae family, was grown as a baby leaf crop, neither ${ }^{15} \mathrm{~N}$ uptake nor $\mathrm{N}$ inflow of rocket (medium at 0.6 and deep at $1.1 \mathrm{~m}$ depths) were any more affected by late-season $\mathrm{N}$ fertiliser $\left(50 \mathrm{~kg} \mathrm{ha}^{-1}\right)$ compared to no $\mathrm{N}$ fertiliser $\left(0 \mathrm{~kg} \mathrm{ha}^{-1}\right)$ (Kristensen and Stavridou 2017).
Root distribution at depth has been shown to be related to soil type. Soil texture is assumed to affect root development because soil properties, such as clay content, soil resistance and porosity, appear to influence root growth (Breuning-Madsen 1985; Mackie-Dawson et al. 1990; Tennant et al. 2001). For example, roots of chicory (Cichorium intybus) were found to reach to $2.5 \mathrm{~m}$ in sandy loam (Thorup-Kristensen 2006), whereas roots only grew to $0.75 \mathrm{~m}$ depth in coarse sand (Askegaard and Eriksen 2007). However, beetroots have been found to grow to more than $1.5 \mathrm{~m}$ depth in both sandy loam and coarse sand (Hefner et al. 2019). In any case, there is a severe lack of knowledge on the relationship between rooting depth and soil texture due to complexities in experimental designs and statistical analysis intending to compare soil types under field conditions. This is due to the confounding influences of variations in climatic conditions, especially when experimental sites are across different geographic regions. Therefore, we conducted two experiments with fodder radish: the effects of soil $\mathrm{N}$ availability and soil type on root growth and $\mathrm{N}$ uptake ability were investigated in a field experiment and a greenhouse experiment. We hypothesized that:

1. High soil $\mathrm{N}_{\text {inorg }}$ availability reduces root intensity and rooting depth of fodder radish and reduces $\mathrm{N}$ uptake from deep soil layers relative to lower $\mathrm{N}_{\text {inorg }}$ availability;

2. Loamy sand reduces root intensity and rooting depth and reduces $\mathrm{N}$ uptake from deep soil layers relative to sandy loam;

3. The rates of $\mathrm{N}$ inflow into roots in deep soil layers are lower at higher soil $\mathrm{N}_{\text {inorg }}$ availability than at lower availability.

The objective of our study is to reveal how high soil $\mathrm{N}$ availability in autumn and soil type influence the ability of fodder radish as an autumn catch crop to deplete deep soil $\mathrm{N}$.

\section{Material and methods}

Field experiment design and agronomic management

The field experiment was conducted in 2010 at the Research Centre AU-Aarslev (Centre) $\left(10^{\circ} 27^{\prime} \mathrm{E}\right.$, $\left.55^{\circ} 18^{\prime} \mathrm{N}\right)$ in Denmark. According to the meteorological 
station at the Centre, the average annual air temperature and precipitation (average for 2006-2009) were $9.2{ }^{\circ} \mathrm{C}$ and $754 \mathrm{~mm}$. Daily precipitation and temperature during the experiment (August to November) are shown in Fig. 1.

A complete randomized block design was applied with four treatments and four replicates. Each plot was $1.4 \mathrm{~m} \times 10 \mathrm{~m}$, established in a conventionally managed field on sandy loam (Typic Agrudalf). Soil attributes were shown in Table 1 according to Xie and Kristensen (2017). Ryegrass was undersown with spring barley (Hordeum vulgare L.) in 2009 and incorporated into soil on 1 December 2009. Barley was grown again in the summer of 2010 and given NPK fertiliser of $500 \mathrm{~kg} \mathrm{ha}^{-1}$ on 14 April $2010(21 \% \mathrm{~N}, 3 \% \mathrm{P}$, and $10 \% \mathrm{~K})$. The soil was ploughed immediately after the barley was harvested on 2 August. A catch crop of fodder radish (cultivar 'Adagio') was sown with a sowing machine on 16 August 2010 at a seeding rate of $20 \mathrm{~kg} \mathrm{ha}^{-1}$. Four experimental treatments were established, which consisted of a combination of two levels of soil $\mathrm{N}$ availability [medium $\mathrm{N}$ (MED-N) and high $\mathrm{N}(\mathrm{HIGH}-\mathrm{N})$ ] and two depths of ${ }^{15} \mathrm{~N}$ injection performed in late autumn (medium at $0.6 \mathrm{~m}$ depth and deep at $1.2 \mathrm{~m}$ depth). (The two injections depths represented, on average, $1 / 3$ and $2 / 3$ of the rooting depth of fodder radish in the field.) To mimic a medium and a high level of residual soil $\mathrm{N}_{\text {inorg }}$ in surface soil after barley harvest, $\mathrm{N}$ fertiliser was applied to the field at two rates on 8 September 2010: $0 \mathrm{~kg} \mathrm{~N} \mathrm{ha}^{-1}$ (MED-N) and $100 \mathrm{~kg} \mathrm{~N} \mathrm{ha}^{-1}$ (HIGH-N). Soil $\mathrm{N}_{\text {inorg }}$ in the field was already $18.7 \mathrm{mg} \mathrm{N} \mathrm{kg}^{-1}$ before the $\mathrm{N}$ fertiliser was supplemented; thus, soil $\mathrm{N}$ concentrations in the MED$\mathrm{N}$ and HIGH-N treatments reached a total $\mathrm{N}_{\text {inorg }}$ availability of 69 and $169 \mathrm{~kg} \mathrm{~N} \mathrm{ha}^{-1}$ in the $0.0-0.25 \mathrm{~m}$ soil layer, respectively. The fertiliser, provided in the form of $370 \mathrm{~kg} \mathrm{ha}^{-1}$ fertiliser (kalkammonsalpeter) to the HIGH-N treatment, contained $27 \% \mathrm{~N}$ in the form of $\mathrm{NH}_{4} \mathrm{NO}_{3}$ and $6 \% \mathrm{CaCO}_{3}$. Irrigation was not given during the growing season of fodder radish.

Root measurement in the field

Minirhizotrons (3-m-long by 70-mm-diameter tubes) were inserted in the field (one per plot) after sowing the fodder radish according to procedures described by Kristensen and Thorup-Kristensen (2004a). We inserted the minirhizotrons into plots at a $30^{\circ}$ angle from vertical with a maximum rooting depth of $2.4 \mathrm{~m}$. Each minirhizotron had two replicates, transparent counting grids, with $40 \times 40 \mathrm{~mm}$ squares painted along the upper $3 \mathrm{~m}$ surface of the tube, symmetrically laid on the left

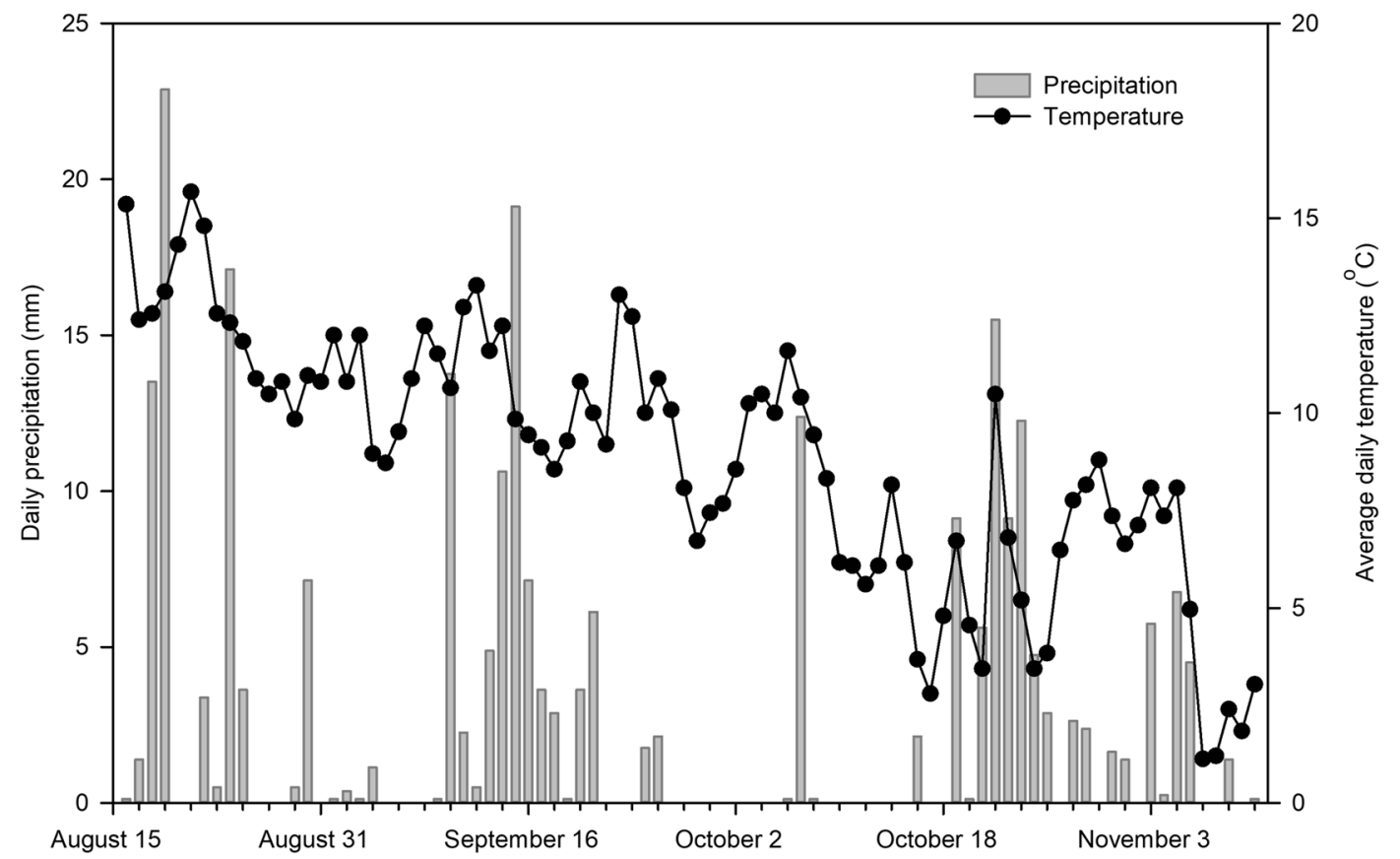

Fig. 1 Daily precipitation and average daily temperatures from the initial sowing of fodder radish to the end of the field experiment 
Table 1 The main characteristics of the soil in the field experiment (soil layers) and in the greenhouse experiment (soil types)

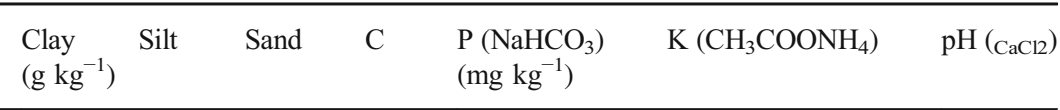

\begin{tabular}{lllllllll}
\hline Field experiment & Soil layer & & & & & & & \\
& $0-0.5 \mathrm{~m}$ & 134 & 151 & 696 & 9 & 24 & 119 & 6.8 \\
& $0.5-1 \mathrm{~m}$ & 188 & 132 & 676 & 2 & 19 & 102 & 5.9 \\
Greenhouse experiment & $1-2.5 \mathrm{~m}$ & 181 & 138 & 678 & 2 & 16 & 105 & 7.3 \\
& & & & & & & & 140 \\
& Sandy loam & 134 & 151 & 696 & 18 & 28 & 9.2 \\
& Loamy sand & 88 & 133 & 742 & 18 & 45 & 92 & 6.8 \\
\hline
\end{tabular}

and right sides of the upper surface of the tube. A minivideo camera was used to obtain images of the roots at the minirhizotrons' surfaces. We measured rooting depth as the deepest root observed relative to each of the two counting grids on each minirhizotron. We recorded root intensity, determined as the total number of roots crossing the grid lines in each 40 -by-40 mm grid and defined as the number of root intersections per meter line (intersections $\left.\mathrm{m}^{-1}\right)$ in a soil layer $(34.6 \mathrm{~mm}$ depth) $\left[\right.$ depth of soil layer $=\cos \left(30^{\circ}\right) \times 40 \mathrm{~mm}$ ]. Both root intensity and rooting depth for each tube were determined from an average of the two counting grids on the tubes, which we recorded for six dates in 2010: 13 September, 23 September, 5 October, 20 October, 1 November and 11 November.

${ }^{15} \mathrm{~N}$ injection in the field

${ }^{15} \mathrm{~N}$ was injected into soil to measure potential $\mathrm{N}$ uptake of plants late in the autumn growth period, 3 November 2010. We chose two injections depths $(0.6 \mathrm{~m}$ and $1.2 \mathrm{~m})$ to access the most intensively rooted part of the root zone. To inject ${ }^{15} \mathrm{~N}$, we made four holes in each subplot $(0.9 \times 0.8 \mathrm{~m})$ with a $20-\mathrm{mm}$ diameter piston rod, following procedures outlined by Kristensen and Thorup-Kristensen (2004a). We placed plastic tubes in each hole to allow the injected ${ }^{15} \mathrm{~N}$ solution to reach the desired depths. The ${ }^{15} \mathrm{~N}$ was injected as a solution of $\mathrm{Na}^{15} \mathrm{NO}_{3}\left(5 \mathrm{mg} \mathrm{N} \mathrm{mL}^{-1}, 99 \%\right.$ ${ }^{15} \mathrm{~N}$ enriched). Each hole was given $5 \mathrm{~mL}$ of $\mathrm{Na}^{15} \mathrm{NO}_{3}$, which provided a total injection of $99 \mathrm{mg}{ }^{15} \mathrm{~N}$ to each subplot. After the ${ }^{15} \mathrm{~N}$ injection, the plastic tubes were rinsed with $25 \mathrm{~mL}$ demineralized water and removed. Wooden rods were inserted in the tube holes to prevent roots growing into the holes.
The greenhouse experiment design

The greenhouse experiment was conducted without artificial light or heat in a complete randomized block design with eight treatments and four replicates from 10 September to 22 November 2010. As in the field experiment, the eight treatments consisted of a combination of two levels of soil $\mathrm{N}$ availability (MED-N and $\mathrm{HIGH}-\mathrm{N}$ ), two ${ }^{15} \mathrm{~N}$ injection depths (medium and deep), and additionally two types of soil [sandy loam from Aarslev and loamy sand from a field in Foulum $\left.\left(56^{\circ} 30^{\prime} \mathrm{N}, 09^{\circ} 35^{\prime} \mathrm{E}\right)\right]$. Therefore, we used 32 rhizotrons, which were 2-m-long transparent Plexiglas tubes with an outer diameter of $100 \mathrm{~mm}$ and inner diameter of $94 \mathrm{~mm}$.

Soil for the greenhouse experiment was obtained from the top $0.25 \mathrm{~m}$ soil layer from a field close to the one of the field experiment at the Centre in Aarslev. Likewise, experimental soil was taken from the top $0.25 \mathrm{~m}$ soil layer in 2010 from a field in Foulum, where barley and wheat had been grown in rotation for several years, in 2010 spring barley. The Foulum soil was a loamy sand (Typic Hapludult). The attributes of the two soil types were shown in Table 1 (Olesen et al. 2004; Xie and Kristensen 2017). All soils were sieved under moist condition through $0.5-\mathrm{cm}$ mesh and then mixed the soils with sand (15\% volume) to provide good aeration and water drainage. Then the soils were manually compacted as uniformly as possible layer by layer to a bulk density of $1.33 \mathrm{Mg} \mathrm{m}^{-3}$. The rhizotrons were covered in black foil with the bottoms perforated for drainage. Soil $\mathrm{N}_{\text {inorg }}$ was determined on 24 August 2010 after mixing it with sand and before packing the soil into rhizotrons. The sandy loam soil contained $19.3 \mathrm{mg} \mathrm{N} \mathrm{kg}$ ${ }^{-1}$ as $\mathrm{NO}_{3}{ }^{-}$and $0.5 \mathrm{mg} \mathrm{N} \mathrm{kg}^{-1}$ as $\mathrm{NH}_{4}{ }^{+}$, whereas the loamy sand soil contained $7.7 \mathrm{mg} \mathrm{N} \mathrm{kg}^{-1}$ as $\mathrm{NO}_{3}{ }^{-}$and 
$1.5 \mathrm{mg} \mathrm{N} \mathrm{kg}{ }^{-1}$ as $\mathrm{NH}_{4}{ }^{+}$. The carbon contents were $18 \mathrm{~g} \mathrm{~kg}^{-1}$ for both soils. For each soil type, the MED$\mathrm{N}$ treatment received no addition of $\mathrm{N}_{\text {inorg }}$ fertiliser, which for the top $0.25 \mathrm{~m}$ soil layer provided final concentrations of $66 \mathrm{~kg} \mathrm{~N}_{\text {inorg }} \mathrm{ha}^{-1}$ in the sandy loam soil and $31 \mathrm{~kg} \mathrm{~N}_{\text {inorg }} \mathrm{ha}^{-1}$ in the loamy sand soil. The HIGH-N treatment had $\mathrm{N}$ fertiliser applied in the form of urea $(46 \% \mathrm{~N})$ to obtain a final concentration in the top $0.25 \mathrm{~m}$ soil layer of $200 \mathrm{~kg} \mathrm{~N} \mathrm{ha}^{-1}$ in both soil types. On 18 September 2010, granulate urea was applied to the soil surface where, after applying irrigation, it immediately dissolved and soaked into the soil. Urea was chosen as $\mathrm{N}$ fertiliser source due to its high solubility, which is an important attribute under the greenhouse conditions. More $\mathrm{N}$ fertiliser (134 and $129 \mathrm{~kg} \mathrm{~N} \mathrm{ha}^{-1}$ for sandy loam and loamy sand, respectively) was applied to soils in the HIGH-N treatment in the greenhouse experiment than to soils in the field experiment $\left(100 \mathrm{~kg} \mathrm{~N} \mathrm{ha}^{-1}\right)$. This extra $\mathrm{N}$ addition was provided to greenhouse plants because they were grown at higher density ( 290 plants $\mathrm{m}^{-2}$ compared to the seeding density of 200 seeds $\mathrm{m}^{-2}$ in the field).

Before the experiment began (on 2 September 2010), seeds of the same fodder radish cultivar as the one used in the field experiment were germinated. On the 10 September, three seedlings with similar appearance were transplanted into rhizotrons that had been irrigated to field capacity two days earlier. The seedlings were positioned half way between the tube centre and the tube wall. Eight days after transplanting (September 18), the two biggest plants were kept in each rhizotron, while the third, poorest-performing plant was removed. Plants were irrigated every third day to maintain its soils at field capacity, based on readings of tension meters installed in the rhizotrons. The average daily temperature in the greenhouse changed from $22^{\circ} \mathrm{C}$ in September to $8{ }^{\circ} \mathrm{C}$ in November.

Root measurements in the greenhouse

Rooting depth was periodically determined by measuring the distance from the soil surface to the point where the deepest root was observed, using the 40 -by-40 mm grids on the rhizotrons as benchmarks. Root intensity was recorded (from the outside surface of the tube) as described for the minirhizotron method in the field experiment (from the inside surface of the tube). The root intensity was recorded on 18 November 2010, which was the day after ${ }^{15} \mathrm{~N}$ injections.

${ }^{15} \mathrm{~N}$ injection in the greenhouse

The ${ }^{15} \mathrm{~N}$ injections were conducted on 17 November 2010, $6 \mathrm{~d}$ before terminating the experiment. Injection depths were based on the rooting depth of the fodder radish. We calculated medium rooting depth in each rhizotron as half of the maximum rooting depth in the rhizotron. Deep depth was defined as $90 \%$ of the maximum depth recorded $1 \mathrm{~d}$ before ${ }^{15} \mathrm{~N}$ was injected into each rhizotron rather than the maximum depth, to ensure the injected ${ }^{15} \mathrm{~N}$ distribution within the rooted zone. This greenhouse ${ }^{15} \mathrm{~N}$ injection procedure and root measurements were done on the same volume of soil from each rhizotron. This differed from the fixed injection depths of 0.6 and $1.2 \mathrm{~m}$ we used in the field experiment, which in turn were based on averages across the crop stand to account for the spatial separation of injections and root measurements in field plots.

In each rhizotron, two pairs of horizontal holes were drilled (two holes at each injection depth) with a power drill. The holes were drilled parallel to one another $25 \mathrm{~mm}$ apart. We drilled through the rhizotron wall and the soil column until the bit reached to the inner side of the opposite wall. Immediately after drilling, $5 \mathrm{~mL}$ of ${ }^{15} \mathrm{~N}$ solution was injected (by syringe) into each hole by inserting the syringe needle into the hole and then pulling it slowly backwards while injecting the solution (to avoid any ${ }^{15} \mathrm{~N}$ from spilling out the hole). The solution was similar to the one we used in the field. After injection, the two holes were covered with airtight black tape to prevent loss of solution and the rhizotron was again covered with black foil.

Plant sampling and analysis

Six days after the ${ }^{15} \mathrm{~N}$ injection (9 November in the field, 22 November in the greenhouse), the shoots and tap roots were harvested from each subplot in the field and rhizotron in the greenhouse for analysis of dry matter, ${ }^{15} \mathrm{~N}$ and $\mathrm{N}$ content. Plant samples were also obtained from additional subplots and rhizotrons to determine background ${ }^{15} \mathrm{~N}$ abundance. All harvested plant samples were separated into shoots and roots. The roots were rinsed with tap water to remove soil, and the plant samples were weighed and kept in plastic bags at $1{ }^{\circ} \mathrm{C}$. We then chopped and mixed the samples in an 
automatic chopping machine, dried them at $80{ }^{\circ} \mathrm{C}$ and weighed them. Then the shoot and root samples from the same sampled plot were assembled as one sample. The assembled samples were mixed and milled and finely grounded to $<0.5 \mathrm{~mm}$ diameter for ${ }^{15} \mathrm{~N}$ analysis. Each plant subsample was analysed for ${ }^{15} \mathrm{~N}$ and total $\mathrm{N}$ content using a PDZ Europa ANCA-GSL elemental analyser interfaced to a PDZ Europa 20-20 Isotope Ratio Mass Spectrometer (Sercon Ltd., Cheshire, UK).

\section{Soil sampling and analysis}

We collected soil samples from the field experiment on 12 November 2010. We used a soil auger (inner diameter $14 \mathrm{~mm}$ ) to remove nine randomly-chosen soil samples to the depth of $2.5 \mathrm{~m}$ from each field plot. Soil samples were divided into depth intervals of $0.0-0.25$, $0.25-0.5,0.5-0.7,0.7-1.1,1.1-1.3,1.3-1.5,1.5-2.0$ and $2.0-2.5 \mathrm{~m}$.

The soil samples were thoroughly mixed from each soil layer in each plot and the mixtures were stored at $-18{ }^{\circ} \mathrm{C}$ for later analysis at a commercial laboratory. Soil $\mathrm{N}_{\text {inorg }}$ was measured with Auto Analyzer3 (Bran + Luebbe, Germany) using standard colorimetric methods. All soil samples were thawed before analysis and immediately extracted in $1 \mathrm{M} \mathrm{KCl}$ for $1 \mathrm{~h}$ (soil: solution ratio $=1: 2$ ). Soil water content was measured by drying the soil to constant weight at $60{ }^{\circ} \mathrm{C}$.

Data calculation and analysis

\section{Calculation of ${ }^{15} N$ uptake and inflow rates}

Because the experimental field design was equivalent to the negative discard method (Powlson and Barraclough 1993), we calculated potential ${ }^{15} \mathrm{~N}$ uptake based on ${ }^{15} \mathrm{~N}$ results according to methods outlined by Kristensen and Thorup-Kristensen (2004b). In addition, the ${ }^{15} \mathrm{~N}$ uptake results were used to calculate root $\mathrm{N}$ inflow rates at each injection depth based on plant $\mathrm{N}$ uptake rates from a given soil volume (Kristensen and Stavridou, 2017). For this procedure, the ${ }^{15} \mathrm{~N}$ solution at each injection point was assumed to be distributed in $1 \mathrm{~L}$ of soil and so adjusted the ${ }^{15} \mathrm{~N}$ enrichment for the dilution effect of the soil $\mathrm{NO}_{3}{ }^{-}$pool measured at each depth (assumed to be $0.3666 \%{ }^{15} \mathrm{~N}$ ). We calculated root length density (the total length of roots per unit of soil volume) from root intensity (Heeraman and Juma 1993) using the modified Newman-line-intersect method for estimating root length (Tennant 1975) and assuming a $2 \mathrm{~mm}$ depth of view from the minirhizotron/rhizotron surface (Kristensen and Thorup-Kristensen 2004a).

\section{Data analysis}

Soil $\mathrm{N}$, biomass, $\mathrm{N}$ accumulation and ${ }^{15} \mathrm{~N}$ were analysed by using the Kenward-Roger method (R software, version 3.6.2), with soil $\mathrm{N}$ availability, injection depth and/ or soil type defined as fixed effects and blocks as random effects, according to the approach of Xie and Kristensen (2017). Data were transformed with the functions $y=x^{1 / 2}$ or $y=\log (x)$ to obtain homogeneity of variance. Root intensity was analysed by using counted number of roots crossing the grid lines $(80 \mathrm{~mm})$ in a $0.25 \mathrm{~m}$ soil layer. The counts were modelled using a GLM defined with a negative binomial distribution due to overdispersion of the counts data. We performed regression analyses between total root intensity in the rooted zone and the accumulated average daily temperature and accumulated daily global radiation from sowing to 1 November 2010. A Pearson's correlation was performed between the total root intensity and the aboveground biomass.

\section{Results}

Plant biomass and $\mathrm{N}$ uptake

The shoot and tap root dry biomass of fodder radish was higher in the HIGH-N treatment than in the MED-N treatment in both field and greenhouse experiments (Table 2). Fodder radish had higher dry biomass in sandy loam soil than in loamy sand soil. In the field experiment, the tap root/shoot ratio was less in the HIGH-N treatment than in the MED-N treatment, whereas we identified the opposite biomass relationship in plant grown under greenhouse conditions.

Rooting depth and distribution

In the field experiment, the rooting depth of fodder radish was similar in the MED-N and HIGH-N treatments. Rooting depth increased over time from $0.51 \mathrm{~m}$ on 13 September to $1.80 \mathrm{~m}$ at the end of experiment (11 November, 86 days after sowing) (results not shown). In the greenhouse experiment, the root system of fodder radish in sandy loam soil was deeper than in loamy sand 
Table 2 Shoot and tap root dry biomass and root/ shoot ratio at harvest in field and greenhouse experiments

\begin{tabular}{|c|c|c|c|c|}
\hline & Conditions & $\begin{array}{l}\text { Shoot } \\
\left(\mathrm{kg} \mathrm{ha}^{-1}\right)\end{array}$ & $\begin{array}{l}\text { Tap root } \\
\left(\mathrm{kg} \mathrm{ha}^{-1}\right)\end{array}$ & Root/shoot ratio \\
\hline \multirow[t]{3}{*}{ Field } & MED-N ${ }^{1}$ & $254.3(10.1) b^{2}$ & $56.4(2.1)$ & $0.22(0.01) \mathrm{a}$ \\
\hline & HIGH-N & $301.9(13.3) \mathrm{a}$ & $48.7(2.8)$ & $0.16(0.01) b$ \\
\hline & & $\left(\right.$ g rhizotron $\left.^{-1}\right)$ & $\left(\right.$ g rhizotron $^{-1}$ ) & \\
\hline \multirow[t]{6}{*}{ Greenhouse } & MED-N & $2.55(0.21) \mathrm{b}$ & $0.52(0.08) b$ & $0.19(0.02) \mathrm{b}$ \\
\hline & HIGH-N & $6.62(0.44) \mathrm{a}$ & $1.73(0.16) \mathrm{a}$ & $0.26(0.02) \mathrm{a}$ \\
\hline & Soil & & & \\
\hline & Sandy loam & $5.53(0.67) \mathrm{a}$ & $1.41(0.22) \mathrm{a}$ & $0.24(0.02)$ \\
\hline & Loamy sand & $3.64(0.45) b$ & $0.84(0.15) b$ & $0.21(0.02)$ \\
\hline & Soil $N$ availability $\times$ Soil type & n.s. ${ }^{3}$ & n.s. & n.s. \\
\hline
\end{tabular}

${ }^{1}$ MED-N and HIGH-N in the field and greenhouse experiments refer to the medium soil $\mathrm{N}$ availability treatment and the high soil $\mathrm{N}$ availability treatment, respectively

${ }^{2}$ Different lower-case letters indicate significant probability difference at $p<0.05$, between $\mathrm{N}$ availability levels or soil types. The numbers in parentheses are standard errors $(\mathrm{SE})(n=8)$

${ }^{3}$ The n.s. means no significance at $p<0.05$

soil from the first measurement date to the end of experiment (Fig. 2). We found no difference in rooting depth between the two levels of soil $\mathrm{N}$ availability. For all $\mathrm{N}$ availabilities in the experimental soils, root system depth was $0.94 \mathrm{~m}$ (in sandy loam) and $0.48 \mathrm{~m}$ (loamy sand) at the first measuring date (5 October, 33 days after sowing). The root system extended to the depth of $1.25 \mathrm{~m}$ (sandy loam) and $0.76 \mathrm{~m}$ (loamy sand) by the end of the experiment (21 November, 79 days after sowing).

For the first $28 \mathrm{~d}$ after sowing (13 September) in the field experiment, root development of fodder radish was slow (Fig. 3), showing the highest root intensity of 11 intersections $\mathrm{m}^{-1}$ in the soil layer at $0.25-0.5 \mathrm{~m}$ under MED-N conditions, and 5 intersections $\mathrm{m}^{-1}$ in the soil layer at $0.0-0.25 \mathrm{~m}$ under HIGH-N conditions. On 23 September, the highest root intensity was in the 0.25 $0.5 \mathrm{~m}$ soil layer with 68 intersections $\mathrm{m}^{-1}$ (under MED$\mathrm{N}$ conditions) and 15 intersections $\mathrm{m}^{-1}$ (under HIGH-N conditions). From 5 October to 11 November, the highest root intensity was in the $0.5-0.75 \mathrm{~m}$ soil layer, whereas root intensity in the $0.25-0.5 \mathrm{~m}(0.5-0.75 \mathrm{~m}$ on 11 November as well) soil layer was higher under the MED-N condition than under the HIGH-N condition.

From 13 to 23 September, fodder radish grown under both MED-N and HIGH-N conditions developed most roots in the top $1 \mathrm{~m}$ of soil (mainly in the $0.25-0.75 \mathrm{~m}$ soil layer) with an increase of 46 intersections $\mathrm{m}^{-1}$ under the MED-N condition and 12 intersections $\mathrm{m}^{-1}$ under the HIGH-N condition. By 5 October, root intensity under both the MED-N and HIGH-N conditions had increased since 23 September: the highest increase in root intensity occurred in the $0.5-0.75 \mathrm{~m}$ soil layer, showing an increase of 45 and 22 intersections $\mathrm{m}^{-1}$ under the MED-N and HIGH-N conditions, respectively. On 20 October, root growth had mainly been in the

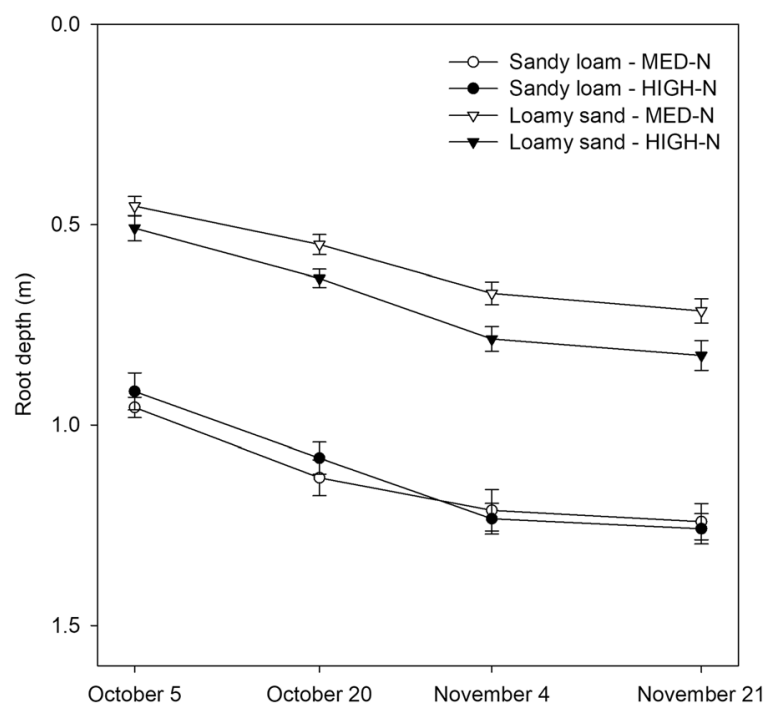

Fig. 2 Rooting depth of fodder radish growing in two soil types (sandy loam from Aarslev and loamy sand from Foulum) in the greenhouse experiment. MED-N and HIGH-N refer to the medium soil $\mathrm{N}$ availability and the high soil $\mathrm{N}$ availability treatments, respectively. The vertical whisker bars indicate standard errors (SE) $(n=4)$ 


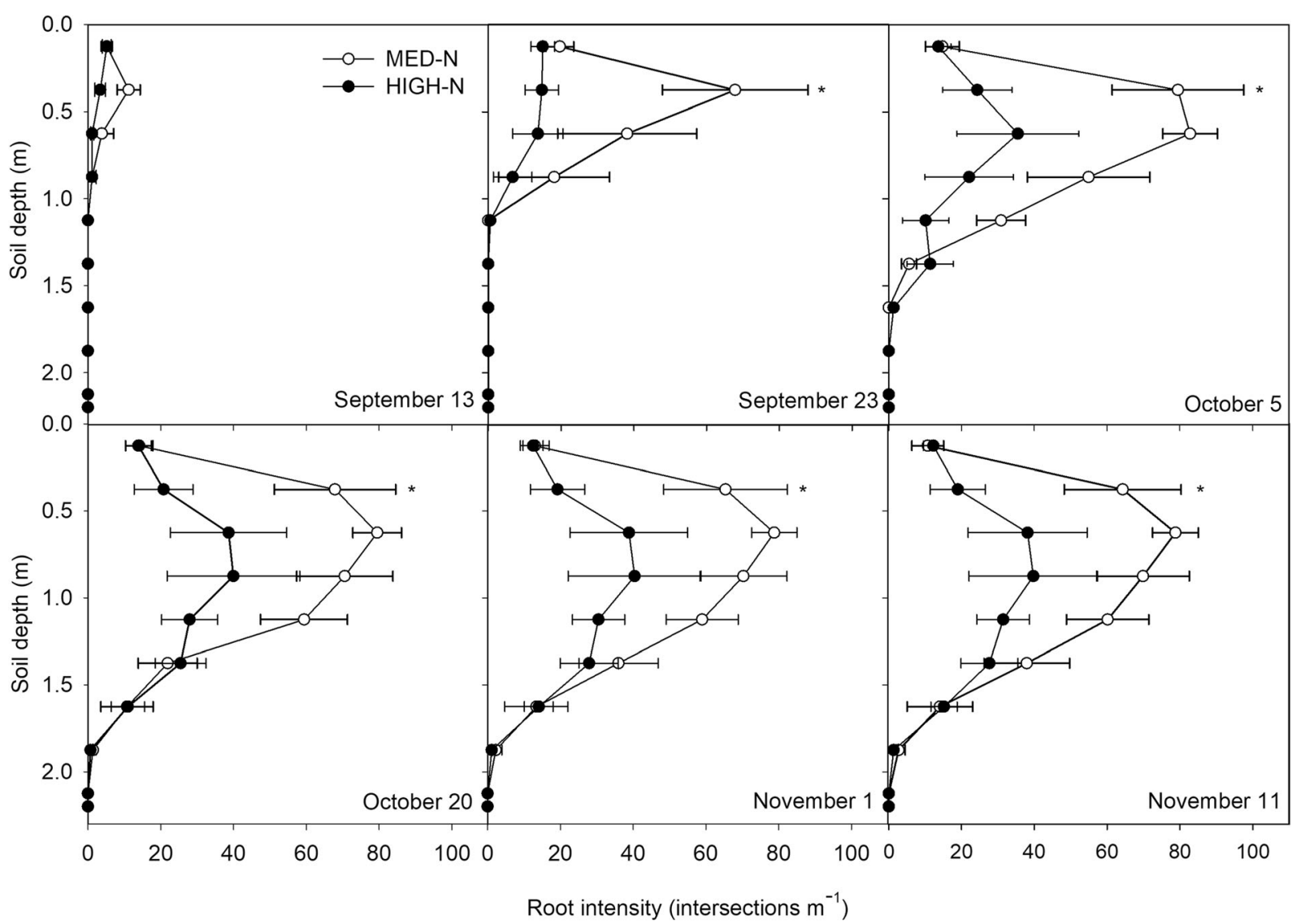

Fig. 3 Root intensity of fodder radish at two $\mathrm{N}$ concentrations in the field experiment. MED-N and HIGH-N refer to the medium soil $\mathrm{N}$ availability and the high soil $\mathrm{N}$ availability treatments,

$0.75-1.75 \mathrm{~m}$ soil layer and the highest increase in root intensity was 29 and 18 intersections $\mathrm{m}^{-1}$ in the 1.0 $1.25 \mathrm{~m}$ soil layer under the MED-N and HIGH-N conditions, respectively. By the last two measurement dates, we observed little additional root growth throughout the root zone from 0 to $2 \mathrm{~m}$ relative to previous measurement dates. Our regression analysis showed that rooting depth and accumulated root intensity of fodder radish in the rooted zone correlates very well with accumulated average daily temperature, based on a 10-d interval of root records compiled from mid-September to 20 October. The rooting depth penetration rate was $3.2 \mathrm{~mm}$ $\mathrm{d}^{-1}{ }^{\circ} \mathrm{C}^{-1}\left(R^{2}=0.97\right)$ (Fig. 4).

In the greenhouse experiment prior to the ${ }^{15} \mathrm{~N}$ experiment (22 November), we found that the highest root intensity was in $0-0.25 \mathrm{~m}$ soil layer in each treatment (Fig. 5). The root intensity in this soil layer was influenced by the interaction between soil type and soil $\mathrm{N}$ respectively. The asterisks $(*)$ indicate significant difference at probabilities $p<0.05$ between $\mathrm{N}$ availability levels. The horizontal whisker bars indicate standard error $(\mathrm{SE})(\mathrm{n}=4)$

availability. Across the soil N-availability spectrum, we found that root intensity of fodder radish in the $0.25-1 \mathrm{~m}$ soil layer was higher in sandy loam soil than in loamy sand soil $(p<0.01)$. Across soil types, the MED-N treatment resulted in lower root intensity in the 0.25 $1 \mathrm{~m}$ soil layer than did the HIGH-N treatment $(p<0.01)$. The sums of root intensity in each rhizotron has a correlation with aboveground biomass $(R=0.76$, $p<0.01)$.

Plant $\mathrm{N},{ }^{15} \mathrm{~N}$ uptake and $\mathrm{N}$ inflow rates

In the field, $\mathrm{N}$ concentration and total $\mathrm{N}$ uptake were higher in HIGH-N treatments than in the MED-N treatments (Table 3). In contrast, ${ }^{15} \mathrm{~N}$ uptake in the HIGH-N treatment was 3.76 and $5.63 \mathrm{mg} \mathrm{subplot}^{-1}$ lower than that in the MED-N treatment at the medium-depth injection and the deep-depth injection points, respectively. 


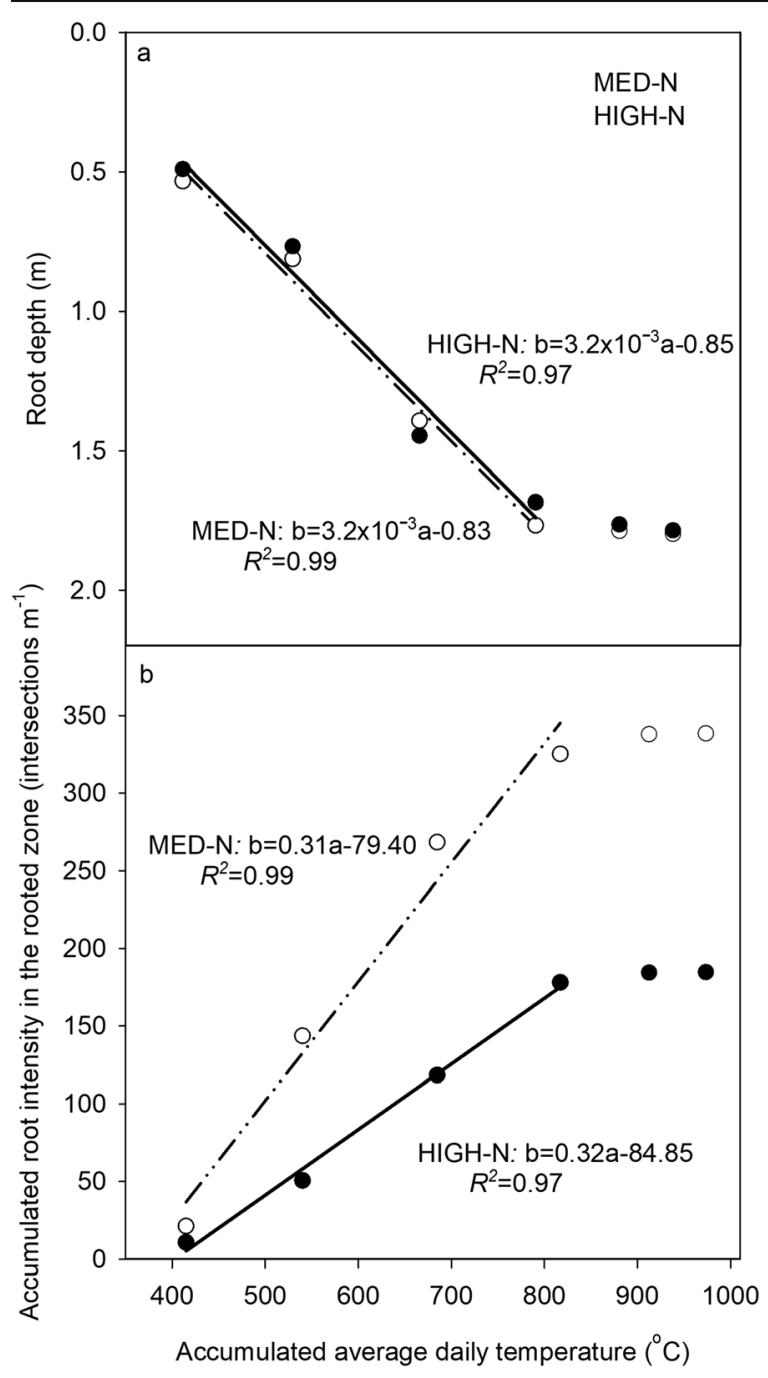

Fig. 4 Rooting depth (a) and accumulated root intensity of fodder radish in the rooted zone (b) versus accumulated average daily temperature from sowing date of 16 August to 11 November in the field experiment, including the outputs of regression analysis (from 16 August to 20 October). MED-N and HIGH-N refer to the medium soil $\mathrm{N}$ availability treatment and the high soil $\mathrm{N}$ availability treatment, respectively

Soil $\mathrm{N}$ availability did not influence $\mathrm{N}$ inflow rates at the medium injection depth, but under conditions of HIGH$\mathrm{N}$ availability, the inflow rate was lower at the deep injection depth. The $\mathrm{N}$ inflow rate under the MED-N conditions was lower at the medium soil depth than at the deep soil depth $(p<0.05)$, whereas under the HIGH$\mathrm{N}$ condition, there was no difference in $\mathrm{N}$ inflow rates between the two injection depths. Similar to the field experiment, total $\mathrm{N}$ uptake of fodder radish in the greenhouse experiment was highest under the HIGH-N condition, whereas the shoot $\mathrm{N}$ concentration was

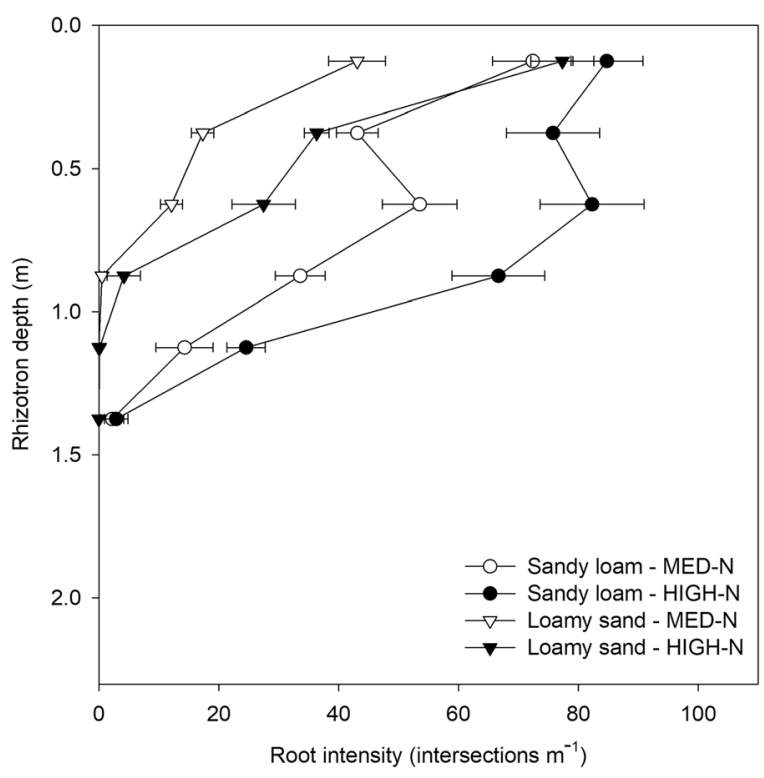

Fig. 5 Root intensity of fodder radish prior to the ${ }^{15} \mathrm{~N}$ injection experiment at two $\mathrm{N}$ levels in sandy loam (from Aarslev) and loamy sand (from Foulum) soils in the greenhouse experiment. MED-N and HIGH-N refer to the medium soil $\mathrm{N}$ availability and the high soil $\mathrm{N}$ availability treatments, respectively. The horizontal whisker bars indicate standard errors $(\mathrm{SE})(n=4)$

influenced neither by soil $\mathrm{N}$ availability nor by soil type (Table 3). There was no interaction between or among soil $\mathrm{N}$ levels, injection depth and soil type. At both injection depths, we found no significant difference in ${ }^{15} \mathrm{~N}$ uptake between soil $\mathrm{N}$ levels or soil types. However, ${ }^{15} \mathrm{~N}$ uptake was higher at the medium injection depth than at the deep injection depth $(p<0.01)$. The $\mathrm{N}$ inflow rate did not differ between medium and deep injection depths, but at the medium depth, the $\mathrm{N}$ inflow rate was higher under the MED-N condition than under the HIGH-N condition and higher in loamy sand than in sandy loam soil. $\mathrm{N}$ inflow at deep injection depth locations tended to be higher under the MED-N treatment than under the HIGH-N treatment $(p=0.07)$, whereas we found no differences in the $\mathrm{N}$ inflow rates between soil types at the deep-injection depth.

Soil $\mathrm{N}_{\text {inorg }}$

In the field experiment, soil $\mathrm{N}_{\text {inorg }}$ before our application of fertiliser was $69 \mathrm{~kg} \mathrm{~N} \mathrm{ha}^{-1}$ in the $0-0.25 \mathrm{~m}$ soil layer and $30 \mathrm{~kg} \mathrm{~N} \mathrm{ha}{ }^{-1}$ in the $0.25-2.5 \mathrm{~m}$ soil layer. The highest soil $\mathrm{N}_{\text {inorg }}$ at the end of experiment was in the $0.0-0.25 \mathrm{~m}$ soil layer in both the MED-N and HIGH-N 
Table 3 Shoot nitrogen $(\mathrm{N})$ concentrations and $\mathrm{N}$ uptake at the end of the field and greenhouse experiments, and ${ }^{15} \mathrm{~N}$ uptake and $\mathrm{N}$ inflow rates during a ${ }^{15} \mathrm{~N}$ injection experiment

\begin{tabular}{|c|c|c|c|c|c|c|}
\hline \multirow[t]{2}{*}{ Conditions } & \multirow{2}{*}{$\begin{array}{l}\mathrm{N} \text { concentration } \\
\left(\mathrm{g} \mathrm{kg}^{-1}\right)\end{array}$} & \multirow{2}{*}{$\begin{array}{l}\text { N uptake } \\
\left(\mathrm{kg} \mathrm{ha}^{-1}\right)\end{array}$} & \multicolumn{2}{|l|}{${ }^{15} \mathrm{~N}$ uptake ${ }^{2}$} & \multicolumn{2}{|c|}{$\mathrm{N}$ inflow (pmol m $\mathrm{m}^{-1} \mathrm{~s}^{-1}$ ) } \\
\hline & & & $\begin{array}{l}\text { Medium } \\
\left(\mathrm{mg} \mathrm{subplot}^{-1}\right)\end{array}$ & Deep & Medium & Deep \\
\hline \multicolumn{7}{|l|}{ Field } \\
\hline MED-N ${ }^{1}$ & $36.4(12.9) b^{3}$ & $113.5(40.1) b$ & $8.12(1.14) \mathrm{a}$ & $8.91(0.59) \mathrm{a}$ & $6.98(0.98) \mathrm{B}$ & $12.13(0.80) \mathrm{aA}$ \\
\hline HIGH-N & $50.2(17.8) \mathrm{a}$ & $175.5(62.1) \mathrm{a}$ & $4.36(0.71) b$ & $3.28(0.54) b$ & $7.34(1.20)$ & $7.53(1.24) b$ \\
\hline $\begin{array}{l}\text { Soil } \mathrm{N} \text { availability } \\
\quad \times \text { Injection depth }\end{array}$ & - & $\left(\mathrm{mg} \mathrm{rhizotron}^{-1}\right)$ & $\begin{array}{l}\text { n.s. } \\
\text { (mg rhizotron }^{-1}\end{array}$ & $\begin{array}{l}\text { n.s. } \\
-1)\end{array}$ & n.s. & n.s. \\
\hline \multicolumn{7}{|l|}{ Greenhouse } \\
\hline MED-N & $17.0(0.6)$ & $57.1(6.3) b$ & $0.76(0.17) \mathrm{A}$ & $0.22(0.04) \mathrm{B}$ & $1.71(0.54) \mathrm{a}$ & $1.19(0.27)$ \\
\hline HIGH-N & $16.2(0.4)$ & $137.9(7.5) \mathrm{a}$ & $0.66(0.08) \mathrm{A}$ & $0.19(0.04) \mathrm{B}$ & $0.76(0.10) b$ & $0.69(0.11)$ \\
\hline \multicolumn{7}{|l|}{ Soil } \\
\hline Sandy loam & $15.3(0.5)$ & $108.5(12.6) \mathrm{a}$ & $0.76(0.12)$ & $0.23(0.04)$ & $0.78(0.16) b$ & $0.76(0.14)$ \\
\hline Loamy sand & $17.8(0.4)$ & $86.5(11.7) b$ & $0.66(0.14)$ & $0.18(0.04)$ & $1.69(0.53) \mathrm{a}$ & $1.12(0.27)$ \\
\hline Soil $\mathrm{N}$ availability $\times$ Soil type & n.s. ${ }^{4}$ & n.s. & n.s. & n.s. & n.s. & n.s. \\
\hline Soil $\mathrm{N}$ availability $\times$ Injection depth & - & - & n.s. & n.s. & n.s. & n.s. \\
\hline Soil type $\times$ Injection depth & - & - & n.s. & n.s. & n.s. & n.s. \\
\hline $\begin{array}{l}\text { Soil } N \text { availability } \\
\quad \times \text { Soil type } \times \text { Injection depth }\end{array}$ & - & - & n.s. & n.s. & n.s. & n.s. \\
\hline
\end{tabular}

${ }^{1}$ MED-N and HIGH-N in the field and greenhouse experiments refer to the medium soil $\mathrm{N}$ availability treatment and the high soil $\mathrm{N}$ availability treatment, respectively

${ }^{2}$ Medium indicates the ${ }^{15} \mathrm{~N}$ injection point at the depth of $0.6 \mathrm{~m}$ in the field experiment, and at half of maximum rooting depth in the greenhouse experiment, whereas Deep indicates the ${ }^{15} \mathrm{~N}$ injection point at the depth of $1.2 \mathrm{~m}$ in the field experiment and at the depth of $90 \%$ of maximum rooting depth in the greenhouse experiment

${ }^{3}$ Different lower-case letters indicate significant difference at $p<0.05$, between $\mathrm{N}$ availability levels or soil types. Different upper-case letters indicate significant difference at $p<0.05$ between injection depth. The numbers in parentheses are standard errors (SE), with $\mathrm{N}$ concentration and $\mathrm{N}$ uptake $(n=8)$ and ${ }^{15} \mathrm{~N}$ uptake and $\mathrm{N}$ inflow $(\mathrm{n}=4)$

${ }^{4}$ The n.s. means no significance at $p<0.05$. The symbol - indicates not relevant

treatments. The HIGH-N treatment had higher soil $\mathrm{N}_{\text {inorg }}$ in all soil layers and therefore higher total soil $\mathrm{N}_{\text {inorg }}$ than the MED-N treatment (Fig. 6). At the end of experiment, soil $\mathrm{N}_{\text {inorg }}$ was $47 \mathrm{~kg} \mathrm{ha}^{-1}$ in the MED-N treatments and $98 \mathrm{~kg} \mathrm{ha}^{-1}$ in the HIGH-N treatment in the $0.0-2.5 \mathrm{~m}$ soil layer.

\section{Discussion}

Root growth of fodder radish in autumn

Few studies have reported the in situ root growth of crops over the autumn season at the temporal and spatial detail employed in our study (Munkholm and Hansen 2012). We found that the root system of fodder radish grows in a similar pattern under medium and high $\mathrm{N}$ conditions in the field. The development of both root intensity and rooting depth was slow in the first month after a mid-August sowing, then growth rate increases in the second month, especially under medium- $\mathrm{N}$ conditions and almost ceases in the third month, suggesting that the root growth of fodder radish mainly occurs before November in Denmark. The rapid root development in the second month after germination is in accordance with a previous study showing that root frequency of fodder radish and dyer's woad (Isatis tinctoria L.) markedly increases from mid-September to midOctober in Denmark (Munkholm and Hansen 2012). In the present study, the high correlation between rooting depth and accumulated average daily temperature and the rooting depth penetration rate of $3.2 \mathrm{~mm}$ 


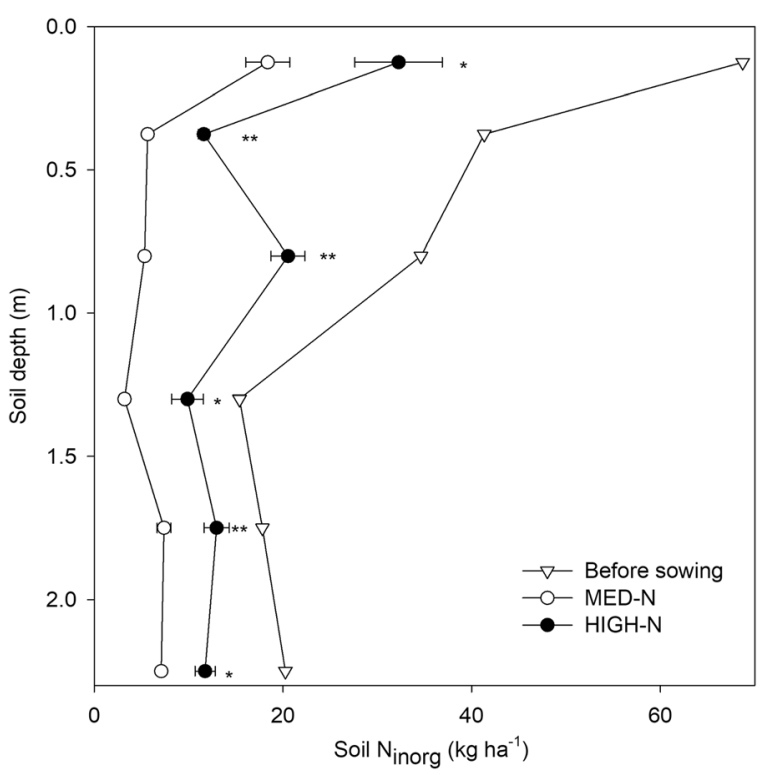

Fig. 6 The distribution of soil inorganic $\mathrm{N}\left(\mathrm{N}_{\text {inorg }}\right)$ prior to sowing of fodder radish and at the end of the ${ }^{15} \mathrm{~N}$ injection experiment on 3 November in the field experiment. MED-N and HIGH-N refer to the medium soil $\mathrm{N}$ availability and the high soil $\mathrm{N}$ availability treatments, respectively. The double asterisks $(* *)$ and single asterisks (*) indicate significant difference between $\mathrm{N}$ availability levels on 3 November at probabilities $p<0.01$ and $p<0.05$, respectively. The horizontal whisker bars indicate standard errors $(\mathrm{SE})(\mathrm{n}=4)$

$\mathrm{d}^{-1}{ }^{\circ} \mathrm{C}^{-1}$ (Fig. 4a) correspond to the good correlation $\left(R^{2}=1\right)$ for the same cultivar of fodder radish grown at the same location reported by a previous study with relatively higher penetration rate of $3.5 \mathrm{~mm} \mathrm{~d}^{-1}{ }^{\circ} \mathrm{C}^{-1}$ (Kristensen and Thorup-Kristensen 2004a). Therefore, our delayed sowing at 16 August (relative to 8 August) could be one reason for the slightly shallower rooting depth $(1.78 \mathrm{~m})$ we recorded by our 20 October sampling $\left(817^{\circ} \mathrm{C}\right)$ than the rooting depths reported by Kristensen and Thorup-Kristensen (2004a): 10 October $\left(871{ }^{\circ} \mathrm{C}\right)$ reading of $1.87 \mathrm{~m}$ rooting depth. However, our study showed that the close relationship between accumulated average daily temperature and rooting depth clearly ceased from 20 October onward, which could not be explained by the decline in global radiation (regression results not shown) nor by the onset of fodder radish flowering, which required long day length and vernalisation in spring for initiation. The cessation of root growth was evident both for rooting depth and root proliferation of the whole root system after 20 October.

The lower root intensity and shallower rooting depth of fodder radish in the present study underscores the factors [such as sowing date (Xie and Kristensen 2017) and accumulated temperature and irradiation in late growing period] that should be taken into account to optimise the effect of autumn catch crops on nitrate leaching.

\section{Effect of soil $\mathrm{N}$ availability on root growth}

We found that soil $\mathrm{N}$ availability affects root growth, but not in the deep part of the root zone. We also found that rooting depth is not affected by soil $\mathrm{N}$ availability across soil types in the field nor under greenhouse conditions, which was not in line with the first part of Hypothesis 1 that high soil $\mathrm{N}$ availability reduces rooting depth. Our lack of a rooting depth/ $\mathrm{N}$-availability relationship matched other studies wherein high soil $\mathrm{N}$ availability did not influence rooting depth of winter wheat (Rasmussen et al. 2015) or sugar beet (Beta vulgaris var. saccharifera) (Vamerali et al. 2003). However, our study results were at odds with Svoboda and Haberle (2006), who found that higher $\mathrm{N}$ causes roots of winter wheat to grow shallower in some years or Kristensen and Stavridou (2017) who found that rooting depth of rocket (also a member of the Brasssicaceae) was deeper in early growth stages. The response of root growth on soil $\mathrm{N}$ availability might be blurred by other factors, such as soil water content, nutrients, deep soil available $\mathrm{N}$, and soil type, as root growth is an integrated result of these factors (Kirkegaard and Lilley 2007; Kristensen and Thorup-Kristensen 2007). Our hypothesis that there would be lower root intensity values under high soil $\mathrm{N}$ availability was confirmed in the field experiment, but not in the greenhouse experiment. A lower root intensity and density at higher soil $\mathrm{N}$ availabilities have been reported from other field experiments, for oilseed rape (Kamh et al. 2005) and broccoli (Brassica oleracea L. var. italic) (both members of Brassicaceae), lettuce (Lactuca sativa L. var. capitata) (Stavridou 2011) and winter wheat (Svoboda and Haberle 2006). The lower root intensity values (with no relationship to rooting depth) in our field experiment indicate that high soil $\mathrm{N}$ availability inhibits lateral root growth of fodder radish. The $\mathrm{N}$ fertilisers we applied in both experiments we assumed would soon be converted to nitrate by urease catalysis and nitrification. The high soil $\mathrm{N}$ availability in surface soils may have met the $\mathrm{N}$ requirement of most crops (Tei et al. 2020) or be sensed by the root systems (Tabata et al. 2014), so the crops may produce fewer roots for nutrient uptake. High concentrations of nitrate might act as a signal rather than a nutrient and thus 
might inhibit lateral root development, at least according to a review on Arabidopsis (Malamy 2005), especially at the stage where lateral roots just emerge from primary roots and subsequently delay activation of lateral root meristem growth (Zhang et al. 1999). Zhang et al. (1999) also suggested that the signal responsible for regulating root development might be via nitrate accumulation in plant tissues, rather than external nitrate concentrations. This suggestion fits with our results and other field studies (Kristensen and ThorupKristensen 2004a; Munkholm and Hansen 2012) wherein there was an opposite response of fodder radish to high soil $\mathrm{N}$ availability in the greenhouse (i.e., $\mathrm{N}$ concentration of fodder radish was much lower than in the field experiment). This root-growth response to $\mathrm{N}$ availability is in line with the assumption that the responses of root growth to soil $\mathrm{N}$ availability depends on a plant's overall performance, such as biomass accumulation and growth rate, and $\mathrm{N}$ status (Kristensen and ThorupKristensen 2007). According to the low N concentrations (Table 3 ) and correlation between aboveground biomass and total root intensity $(R=0.76, p<0.01)$, we assumed that severe $\mathrm{N}$ deficiency in the greenhouse experiment, could hinder photosynthesis in plants (Zhao et al. 2005) and may result in reduced amount of photosynthates translocated to roots for proliferation. The inhibition of fodder radish growth (shoot and root) was mitigated when we increased soil $\mathrm{N}$ availability to $200 \mathrm{~kg} \mathrm{~N} \mathrm{ha}^{-1}$ (thus inhibiting a N deficiency). Similar to our results, Feng et al. (2016) found that root growth of maize increased with higher $\mathrm{N}$ fertilisation to a maximum of 168 or $240 \mathrm{~kg} \mathrm{~N} \mathrm{ha}^{-1}$ in different soil types and then declined with higher additions of $\mathrm{N}$. The differential responses of fodder radish to high soil $\mathrm{N}$ availability between the field and greenhouse experiments emphasizes the sophisticated responses of plant root systems to soil nitrate content (Zhang et al. 2007).

\section{Effect of soil $\mathrm{N}$ availability on $\mathrm{N}$ uptake}

The high soil $\mathrm{N}$ availability in surface soil lessened fodder radish's potential for depleting soil $\mathrm{N}_{\text {inorg }}$ in late autumn, though fodder radish $\mathrm{N}$ uptake was highest during the first part of the autumn growing period. The lower potential of fodder radish for depleting soil $\mathrm{N}_{\text {inorg }}$ was exhibited both by lower crop ${ }^{15} \mathrm{~N}$ uptake in the field and lower $\mathrm{N}$ inflow into roots in both field and greenhouse experiments (Table 3 , deep soil depths $(p=0.07$ ) in the greenhouse). Both ${ }^{15} \mathrm{~N}$ uptake and $\mathrm{N}$ inflow were within the range of $\mathrm{N}$ inflows reported from other field experiments (Kristensen and Thorup-Kristensen 2004a, b). These results are in line with a field study of maize by Gass et al. (1971) and confirms the second part of Hypothesis 1 that high soil $\mathrm{N}$ availability leads to less $\mathrm{N}$ uptake from deep soil layers. This finding of lower ${ }^{15} \mathrm{~N}$ uptake in response to high soil $\mathrm{N}$ in our field experiment can be ascribed to lower $\mathrm{N}$ demand by plants indicated by the higher $\mathrm{N}$ status (shoot $\mathrm{N}$ concentration) and the lower $\mathrm{N}$ inflow at the deeper depths in the soil $(38 \%$ lower than at medium soil $\mathrm{N}$ availability), and/or to the lower root intensity (Fig. 3), which has a linear relationship with ${ }^{15} \mathrm{~N}$ uptake (Kristensen and ThorupKristensen 2004a, b).

Importantly, the $\mathrm{N}$ inflow rate under medium- $\mathrm{N}$ soil conditions is almost double at deep soil depths than at medium soil depths in the field $(p<0.05)$ (Table 3$)$, suggesting higher potential for plants to uptake $\mathrm{N}_{\text {inorg }}$ in deep soil at medium soil $\mathrm{N}$ availability than at a medium soil depth. This difference in uptake with depth was possibly due to a more active $\mathrm{N}$ uptake by younger roots (Reidenbach and Horst 1997), shown by the highest increase in amount of root intensity in the $1.0-1.25 \mathrm{~m}$ soil layer during the late period of our study (5-20 October), just before root growth ceased. In contrast, there was no root intensity increase in the $0.5-0.75 \mathrm{~m}$ soil layer. The more active $\mathrm{N}$ uptake by younger roots was not observed at high soil $\mathrm{N}$ availability, probably because the active $\mathrm{N}$ uptake was overshadowed by a lower $\mathrm{N}$ demand of fodder radish at high soil $\mathrm{N}$ availability. Similarly, rocket grown on a coarse sandy soil at high soil $\mathrm{N}$ availability shows no difference in $\mathrm{N}$ inflows at medium and deep soil depths (Kristensen and Stavridou 2017).

The higher $\mathrm{N}$ inflow rates in deep roots in fodder radish under conditions of medium soil $\mathrm{N}$ availability suggest that deep roots may contribute more to crop $\mathrm{N}$ uptake than indicated by their root abundance alone, not only over the longer term (a growing season) due to the mobility of nitrate in soil solution (Thorup-Kristensen 2001), but also in the shorter term (several days or a growing stage) due to the younger and more active roots compared to those in medium soil layers. On the other hand, the older and less active roots in medium depth may be a possible reason for lacking response of $\mathrm{N}$ inflow to soil $\mathrm{N}$ availability (Table 3 ).

Deep soil $\mathrm{N}_{\text {inorg }}$ depletion has been shown to correlate with rooting depth (Sapkota et al. 2012; ThorupKristensen 2001), but may also be influenced by root activity (Reidenbach and Horst 1997), shoot N uptake at 
maturity (Wiesler and Horst 1994) and deep distribution of root density (Pedersen et al. 2010), which determine the volume of soil exploited by root systems to approach nutrients, especially in deep soil layers. However, in this present study, the reduced ability of fodder radish to deplete deep soil $\mathrm{N}_{\text {inorg }}$ was not mainly a response to an alteration of its root system because we found no difference in rooting depth and root intensity in deep soil layers. Additionally, the higher $\mathrm{N}$ uptake of fodder radish under high- $\mathrm{N}$ conditions in the field $\left(62 \mathrm{~kg} \mathrm{ha}^{-1}\right.$ higher) and under greenhouse conditions and all soil types (117 $\mathrm{kg} \mathrm{ha}^{-1}$ higher) is suspected due to higher biomass (in both the field and greenhouse) and $\mathrm{N}$ concentration (in the field) of fodder radish compared to under medium- $\mathrm{N}$ conditions. The higher $\mathrm{N}$ uptake under high- $\mathrm{N}$ conditions further indicates that high soil $\mathrm{N}$ availability mainly reduces the $\mathrm{N}$ inflow of fodder radish and subsequently deep soil $\mathrm{N}_{\text {inorg }}$ depletion by meeting fodder radish's $\mathrm{N}$ demand (higher $\mathrm{N}$ concentration in fodder radish), rather than by alterations to the root systems. However, the higher $\mathrm{N}$ uptake we found under high- $\mathrm{N}$ conditions could not counterbalance the difference in the amounts of available $\mathrm{N}$ in soil $\left(100 \mathrm{~kg} \mathrm{~N} \mathrm{ha}^{-1}\right.$ in the field and $167 \mathrm{~kg} \mathrm{~N} \mathrm{ha}^{-1}$ in the greenhouse), leaving more $\mathrm{N}_{\text {inorg }}$ in soil layers at the end of field experiment $\left(35,7\right.$ and $10 \mathrm{~kg} \mathrm{ha}^{-1}$ in the $0.0-1.1 \mathrm{~m}$, $1.1-1.5 \mathrm{~m}$ and $1.5-2.5 \mathrm{~m}$ soil layers, respectively) (Fig. 6).

The effect of soil type on root growth and $\mathrm{N}$ uptake from deep soil layers

Fodder radish developed a shallower root system and lower root intensity in loamy sand than in sandy loam soil, probably due to the difference in clay content and available P of the two soil textures. This result supports Hypothesis 2 that root intensity and rooting depth will be lower in loamy sand than sandy loam like for chicory. It reached a rooting depth of $2.5 \mathrm{~m}$ in sandy loam (Thorup-Kristensen 2006), whereas it was only $0.75 \mathrm{~m}$ in coarse sand (Askegaard and Eriksen 2007), regardless of climatic and edaphic conditions, such as soil $\mathrm{N}$ availability. Meanwhile when compared in the same study, beetroot was found to grow deeper than $1.5 \mathrm{~m}$ depth in both sandy loam and coarse sand (Hefner et al., 2019). In our present study, due to the similar bulk densities of two soils in the greenhouse experiment, the deeper rooting depth and higher root intensity of fodder radish growing in sandy loam than in loamy sand soil might not be ascribed to mechanical impedance, aeration, or soil hydraulic conductivity, factors that have been identified in other studies as causing differences in root growth among soil types (Mackie-Dawson et al. 1990; Tennant et al. 2001). Some possible explanations for difference in root growth could be ascribed to differences in clay content. Because the optimal clay content for root growth is about 10\%-20\% (Breuning-Madsen 1985 ), the $13.4 \%$ clay in our sandy loam soil could have provided more favourable conditions for root growth than the $8.8 \%$ clay content in our loamy sand soil. In addition, the lower available $\mathrm{P}$ in sandy loam $\left(28 \mathrm{mg} \mathrm{kg}^{-1}\right)$ than in loamy sand $\left(45 \mathrm{mg} \mathrm{kg}^{-1}\right)$ (Table 1) might have also stimulated root growth in the sandy loam (Hodge 2004).

The more limited rooting depth and distribution of fodder radish in loamy sand than in sandy loam may indicate a weaker ability to deplete deep soil $\mathrm{N}_{\text {inorg. }}$. We incorporated difference in rooting depth when we decide to use the injection depths of $50 \%$ and $90 \%$ of total rooting depth. At the medium injection depth (loamy sand: $0.4 \mathrm{~m}$; sandy loam: $0.7 \mathrm{~m}$ ), we found a higher potential for soil $\mathrm{N}_{\text {inorg }}$ depletion in loamy sand soil than in sandy loam, suggested by the higher $\mathrm{N}$ inflow rate in loamy sand. However, we speculate that the root intensity at the medium injection in sandy loam, twice that in loamy sand, counteracts the lower $\mathrm{N}$ inflow rate in sandy loam, resulting in similar ${ }^{15} \mathrm{~N}$ uptake for both soil types. The ${ }^{15} \mathrm{~N}$ uptake and $\mathrm{N}$ inflow did not differ significantly at the deep injection depth (loamy sand: $0.6 \mathrm{~m}$; sandy loam: $1.1 \mathrm{~m}$ ), whereas the ability of fodder radish to deplete deep soil $\mathrm{N}_{\text {inorg }}$ may be more limited in loamy sand due to the shallower depth of rooting there than in the sandy loam (Fig. 2). Both the availability of soil $\mathrm{N}$ and soil physical characteristics likely influence root growth, and consequently, the ability of fodder radish to deplete deep soil $\mathrm{N}_{\text {inorg. }}$.

\section{Conclusions}

High soil $\mathrm{N}$ availability is related to more vigorous shoot growth and higher $\mathrm{N}$ concentrations in fodder radish, but is related to less root growth in field plots opposite in greenhouse plants. High soil $\mathrm{N}$ availability in late autumn causes lower ${ }^{15} \mathrm{~N}$ uptake in field plots and lower $\mathrm{N}$ inflow rates in both experimental setups, which results in higher residual $\mathrm{N}$ in soils. High $\mathrm{N}$ availability lowers the $\mathrm{N}$ demand of fodder radish in late autumn, reflected 
by the lower $\mathrm{N}$ inflow rates at deep soil depth (field) and medium soil depth (greenhouse). Deep roots may contribute relatively more to $\mathrm{N}$ uptake from deep soil layers due to their higher $\mathrm{N}$ inflow rates than shallower roots at medium soil $\mathrm{N}$ availabilities. The different responses of root growth to soil $\mathrm{N}$ availability in the field and greenhouse experiments are likely due to differences in the $\mathrm{N}$ status of fodder radish. Rooting depth and root distribution are more limited in loamy sand soil than in sandy loam soil, probably due to the low clay and high $\mathrm{P}$ content of the loamy sand.

Acknowledgements This work was financed by the N-toolbox project (EU FP7) and Department of Food Science, Aarhus University. We appreciated the skilled technical assistance by Birthe Flyger, Astrid Bergmann and Jens Elkjær.

Open Access This article is licensed under a Creative Commons Attribution 4.0 International License, which permits use, sharing, adaptation, distribution and reproduction in any medium or format, as long as you give appropriate credit to the original author(s) and the source, provide a link to the Creative Commons licence, and indicate if changes were made. The images or other third party material in this article are included in the article's Creative Commons licence, unless indicated otherwise in a credit line to the material. If material is not included in the article's Creative Commons licence and your intended use is not permitted by statutory regulation or exceeds the permitted use, you will need to obtain permission directly from the copyright holder. To view a copy of this licence, visit http://creativecommons.org/licenses/by/4.0/.

\section{References}

Askegaard M, Eriksen J (2007) Growth of legume and nonlegume catch crops and residual-N effects in spring barley on coarse sand. J Plant Nutr Soil Sci 170:773-780. https://doi. org/10.1002/jpln.200625222

Breuning-Madsen H (1985) Distribution of spring barley roots in Danish soils, of different texture and under different climatic conditions. Plant Soil 88:31-43. https://doi.org/10.1007 /bf02140664

Ebrahimi E, Bodner G, Kaul HP, Nassab ADM (2014) Effects of water supply on root traits and biological yield of durum (Triticum durum Desf.) and Khorasan (Triticum turanicum Jakubz) wheat. Plant Biosyst 148:1009-1015. https://doi. org/10.1080/11263504.2013.850120

Farneselli M, Tosti G, Onofri A, Benincasa P, Guiducci M, Pannacci E, Tei F (2018) Effects of N sources and management strategies on crop growth, yield and potential $\mathrm{N}$ leaching in processing tomato. Eur J Agron 98:46-54. https://doi.org/10.1016/j.eja.2018.04.006

Feng G, Zhang Y, Chen Y, Li Q, Chen F, Gao Q, Mi G (2016) Effects of nitrogen application on root length and grain yield of rain-fed maize under different soil types. Agron J 108: 1656-1665. https://doi.org/10.2134/agronj2015.0367
Gabriel JL, Muñoz-Carpena R, Quemada M (2012) The role of cover crops in irrigated systems: water balance, nitrate leaching and soil mineral nitrogen accumulation. Agric Ecosyst Environ 155:50-61. https://doi.org/10.1016/j. agee.2012.03.021

Gass WB, Peterson GA, Hauck RD, Olson RA (1971) Recovery of residual nitrogen by corn (Zea mays L.) from various soil depths as measured by N-15 tracer techniques. Soil Sci Soc Am Proc 35:290-294

Heeraman DA, Juma NG (1993) A comparison of minirhizotron, core and monolith methods for quantifying barley (Hordeum vulgare L.) and fababean (Vicia faba L.) root distribution. Plant Soil 148:29-41. https://doi.org/10.1007/bf02185382

Hefner M, Labouriau R, Nørremark M, Kristensen HL (2019) Controlled traffic farming increased crop yield, root growth, and nitrogen supply at two organic vegetable farms. Soil Till Res 191:117-130. https://doi.org/10.1016/j.still.2019.03.011

Herrera JM, Noulas C, Feil B, Stamp P, Liedgens M (2013) Nitrogen and genotype effects on root growth and root survivorship of spring wheat. J Plant Nutr Soil Sci 176:561-571. https://doi.org/10.1002/jpln.201100334

Hodge A (2004) The plastic plant: root responses to heterogeneous supplies of nutrients. New Phytol 162:9-24. https://doi. org/10.1111/j.1469-8137.2004.01015.x

Kamh M, Wiesler F, Ulas A, Horst WJ (2005) Root growth and Nuptake activity of oilseed rape (Brassica napus L.) cultivars differing in nitrogen efficiency. J Plant Nutr Soil Sci 168: 130-137. https://doi.org/10.1002/jpln.200421453

Kang L, Yue S, Li S (2014) Effects of phosphorus application in different soil layers on root growth, yield, and water-use efficiency of winter wheat grown under semi-arid conditions. J Integr Agric 13:2028-2039. https://doi.org/10.1016/S20953119(14)60751-6

Kirkegaard JA, Lilley JM (2007) Root penetration rate a benchmark to identify soil and plant limitations to rooting depth in wheat. Aust J Exp Agric 47:590-602. https://doi.org/10.1071 /EA06071

Kristensen HL, Stavridou E (2017) Deep root growth and nitrogen uptake by rocket (Diplotaxis tenuifolia L.) as affected by nitrogen fertilizer, plant density and leaf harvesting on a coarse sandy soil. Soil Use Manag 33:62-71. https://doi. org/10.1111/sum. 12334

Kristensen HL, Thorup-Kristensen K (2004a) Root growth and nitrate uptake of three different catch crops in deep soil layers. Soil Sci Soc Am J 68:529-537. https://doi. org/10.2136/sssaj2004.5290

Kristensen HL, Thorup-Kristensen K (2004b) Uptake of N-15 labeled nitrate by root systems of sweet corn, carrot and white cabbage from 0.2-2.5 meters depth. Plant Soil 265:93-100. https://doi.org/10.1007/s11104-005-0696-y

Kristensen HL, Thorup-Kristensen K (2007) Effects of vertical distribution of soil inorganic nitrogen on root growth and subsequent nitrogen uptake by field vegetable crops. Soil Use Manag 23:338-347. https://doi.org/10.1111/j.14732743.2007.00105.x

Mackie-Dawson LA, Millard P, Robinson D (1990) Nutrient uptake by potato crops grown on two soils with contrasting physical properties. Plant Soil 125:159-168. https://doi. org/10.1007/bf00010653 
Malamy JE (2005) Intrinsic and environmental response pathways that regulate root system architecture. Plant Cell Environ 28: 67-77. https://doi.org/10.1111/j.1365-3040.2005.01306.x

Munkholm LJ, Hansen EM (2012) Catch crop biomass production, nitrogen uptake and root development under different tillage systems. Soil Use Manag 28:517-529. https://doi. org/10.1111/Sum.12001

Olesen JE, Askegaard M, Berntsen J (2004) Nitrate leaching from arable crop rotations in organic farming. Controlling nitrogen flows and losses, proceedings of the 12th $\mathrm{N}$ workshop. Pp 389-396, Exeter, Devon, UK

Pedersen A, Zhang K, Thorup-Kristensen K, Jensen L (2010) Modelling diverse root density dynamics and deep nitrogen uptake-a simple approach. Plant Soil 326:493-510. https://doi.org/10.1007/s11104-009-0028-8

Powlson D, Barraclough D (1993) Mineralization and assimilation in soil-plant systems. In: Melillo J, Blackburn H (eds) EAP Roger Knowles. Nitrogen isotope techniques. Academic Press, San Diego, pp 209-242

Rasmussen IS, Dresbøll DB, Thorup-Kristensen K (2015) Winter wheat cultivars and nitrogen $(\mathrm{N})$ fertilization-effects on root growth, $\mathrm{N}$ uptake efficiency and $\mathrm{N}$ use efficiency. Eur $\mathrm{J}$ Agron 68:38-49. https://doi.org/10.1016/j.eja.2015.04.003

Reidenbach G, Horst WJ (1997) Nitrate-uptake capacity of different root zones of Zea mays (L.) in vitro and in situ. In: Ando T, Fujita K, Mae T, Matsumoto H, Mori S, Sekiya J (eds) Plant nutrition for sustainable food production and environment: proceedings of the XIII international plant nutrition colloquium. Springer Netherlands, Dordrecht, pp 663-668

Sapkota TB, Askegaard M, Laegdsmand M, Olesen JE (2012) Effects of catch crop type and root depth on nitrogen leaching and yield of spring barley. Field Crop Res 125:129-138. https://doi.org/10.1016/j.fcr.2011.09.009

Stavridou E (2011) The effect of cropping systems on selenium and glucosinolate concentration in vegetables. University, Aarhus

Svoboda P, Haberle J (2006) The effect of nitrogen fertilization on root distribution of winter wheat. Plant Soil Environ 52:308313

Tabata R, Sumida K, Yoshii T, Ohyama K, Shinohara H, Matsubayashi Y (2014) Perception of root-derived peptides by shoot LRR-RKs mediates systemic N-demand signaling. Science 346:343-346. https://doi.org/10.1126 /science. 1257800

Tei F, De Neve S, de Haan J, Kristensen HL (2020) Nitrogen management of vegetable crops. Agric Water Manag 240: 106316. https://doi.org/10.1016/j.agwat.2020.106316
Tennant D (1975) A test of a modified line intersect method of estimating root length. J Ecol 63:995-1001. https://doi. org/10.2307/2258617

Tennant D, Tennant D, Hall D, Hall D (2001) Improving water use of annual crops and pastures - limitations and opportunities in Western Australia. Aust J Agric Res 52:171-182. https://doi.org/10.1071/AR00005

Thorup-Kristensen K (1994) The effect of nitrogen catch crop species on the nitrogen nutrition of succeeding crops. Fert Res 37:227-234. https://doi.org/10.1007/bf00748941

Thorup-Kristensen K (2001) Are differences in root growth of nitrogen catch crops important for their ability to reduce soil nitrate-N content, and how can this be measured? Plant Soil 230:185-195. https://doi.org/10.1023/A:1010306425468

Thorup-Kristensen K (2006) Effect of deep and shallow root systems on the dynamics of soil inorganic $\mathrm{N}$ during 3-year crop rotations. Plant Soil 288:233-248. https://doi. org/10.1007/s11104-006-9110-7

Vamerali T, Ganis A, Bona S, Mosca G (2003) Fibrous root turnover and growth in sugar beet (Beta vulgaris var. saccharifera) as affected by nitrogen shortage. Plant Soil 255:169-177. https://doi.org/10.1023/a:1026187017605

Wiesler F, Horst WJ (1994) Root growth and nitrate utilization of maize cultivars under field conditions. Plant Soil 163:267277. https://doi.org/10.1007/bf00007976

Xie Y, Kristensen HL (2017) Intercropping leek (Allium porrum L.) with dyer's woad (Isatis tinctoria L.) increases rooted zone and agro-ecosystem retention of nitrogen. Eur J Agron 82, part a: 21-32 https://doi.org/10.1016/j.eja.2016.09.017

Zhang H, Rong H, Pilbeam D (2007) Signalling mechanisms underlying the morphological responses of the root system to nitrogen in Arabidopsis thaliana. J Exp Bot 58:23292338. https://doi.org/10.1093/jxb/erm114

Zhang HM, Jennings A, Barlow PW, Forde BG (1999) Dual pathways for regulation of root branching by nitrate. P Natl Acad Sci USA 96:6529-6534. https://doi.org/10.1073 /pnas.96.11.6529

Zhao DL, Reddy KR, Kakani VG, Reddy VR (2005) Nitrogen deficiency effects on plant growth, leaf photosynthesis, and hyperspectral reflectance properties of sorghum. Eur J Agron 22:391-403. https://doi.org/10.1016/j.eja.2004.06.005

Publisher's note Springer Nature remains neutral with regard to jurisdictional claims in published maps and institutional affiliations. 